This item was submitted to Loughborough's Research Repository by the author.

Items in Figshare are protected by copyright, with all rights reserved, unless otherwise indicated.

\title{
The multicultural dilemma: between normative and practical reasoning
}

PLEASE CITE THE PUBLISHED VERSION

http://dx.doi.org/10.1177/2043820612449540

\section{PUBLISHER}

Sage (@ The authors)

\section{VERSION}

AM (Accepted Manuscript)

\section{PUBLISHER STATEMENT}

This work is made available according to the conditions of the Creative Commons Attribution-NonCommercialNoDerivatives 4.0 International (CC BY-NC-ND 4.0) licence. Full details of this licence are available at: https://creativecommons.org/licenses/by-nc-nd/4.0/

\section{LICENCE}

CC BY-NC-ND 4.0

\section{REPOSITORY RECORD}

Antonsich, Marco. 2019. "The Multicultural Dilemma: Between Normative and Practical Reasoning”. figshare. https://hdl.handle.net/2134/16109. 


\title{
The multicultural dilemma
}

\section{between normative and practical reasoning}

\author{
Marco Antonsich \\ Central European University
}

'The multicultural dilemma', i.e., how to reconcile equal dignity with difference, is the central question around which Randi Gressgård’s book revolves. As a way to excavate the conceptual underpinnings of this dilemma, Gressgård embarks in a rich philosophical journey through the texts of, among others, Kant, Lyotard, Lash, Gadamer, Falzon, and Kögler. Her writing strategy is one which expressly tries to let the others speak in her text, avoiding the elevation of the central thinking 'I' (p. xiii). This strategy, she maintains, is in line with her theoretical argument for an open dialogue, respectful of difference, which, as I will explain below, is her 'solution' to the multicultural dilemma.

I should say that if, on the one hand, I sympathize with the rationale of this strategy, on the other hand, I have at times found myself a bit lost and confused while following Gressgård's philosophical journey. Being used to traditional academic writing, where the 'I' of the author continuously steps in to tell the reader where s/he stands, in the case of Gressgård I struggled to find her voice and therefore to locate the relevance of other authors' reasoning within her main line of argument. It is comforting to think, though, that a feeling of being lost and confused can resonate, in Gressgård, with a sense of lack 
or inadequacy of our intellectual categories, which in turn is the necessary condition for an open dialogue...

At risk of elevating my 'I', there are two major points which nonetheless I would like to make in relation to Gressgård's book. The first concerns her preference for a theoretical approach versus an empirical one. The theoretical approach adopted by Gressgård is indeed one which "frees the analysis from the constraints of what empirical analysis by itself is able to reveal" (p. xii). Such a theoretical approach is thus able "to illuminate and discuss otherwise unchallenged assumptions that are constitutive of multiculturalism and multicultural dialogue” (p. xii). I should say that I am a bit perplexed about this division between the theoretical and the empirical, as I believe in the mutually constituent relationship between these two dimensions. By overlooking empirical analysis, one indeed risks falling prey of the seductive power of the inner logic of the theoretical reasoning itself, with its pure, linear, consequential way of putting all the pieces together, so to speak. We all know that reality is much more dirty, messy and inconsequential. The problem here is not only with the logical incongruence between a theoretical ‘solution' (being open to difference) and a practical problem (the multicultural dilemma), but with the accuracy of a theoretical reasoning which is not informed by empirical analysis. Let me make a few examples to explain this point.

Following Falzon (1998), Gressgård argues that we are in a position to be open to dialogue when our prevailing categories are being challenged by the 'other' (p. 129). While this is the logical conclusion of her theoretical reasoning, in practice we often observe a defensive, xenophobic attitude exactly when economic, social, and cultural certainties are challenged by the 'other' (Brader et al. 2008; Citrin and Sides 2008). Even 
if we accept that this empirical finding might not per se invalidate the theoretical argument for an open dialogue in the context of an 'identity crisis', it demands nevertheless a more refined theoretical argument, which specifies, for instance, under which conditions an open dialogue might take place. Far from being a 'constraint', the empirical can 'illuminate' further the theory.

Similarly, I believe that Gressgård’s theoretical reasoning on the assimilation/culturalisation of the 'other' could have benefited from the empirical analysis on the actual dynamics of the assimilation process. In fact, as the rich literature on neo-assimilation has shown (see, for instance, Alba and Nee 1997), assimilation is not necessarily a forced condition, as migrants themselves are active subjects in the process of 'becoming similar' (Brubaker 2001; Nagel 2009). This points to the theoretical relevance of the agency of the 'other' - a dimension only marginally discussed in the book and always in terms of potential resistance to assimilation. Taking into account the desire of the 'other' to become 'the Same' would certainly open the multicultural dilemma to new and different theoretical questions.

The second point which I want to make is closely tied with the first one and concerns Gressgård’s ‘solution’ to the multicultural dilemma. Gressgård explicitly aims to move beyond the liberal, universalist notion of equality and the cultural relativist notion of distinctiveness, since, according to her, both converge in a process of ethnocentric assimilation and culturalisation/subordination of the 'other'. On the one hand, in fact, the liberal notion of equality assumes a universal, modern, de-culturalised subject as a principle of both inclusive humanity and dominant moral universe, against which any heterogeneity is excluded. In other words, since the cultural order of modern liberal 
Western societies is granted a universal status with an exclusive right to define equality, those who are not identified with this universal civic public are repressed, subordinated, assimilated or excluded. As such, the liberal ideal of individual equality translates into an ethno-centric principle which justifies inequality (p. 38-40). On the other hand, the cultural relativism practiced by multiculturalism is, for Gressgård, equally to blame, since it "constantly run[s] the risk of assimilating the unspeakable into existing norms of dominance by way of managing and regulating difference, often in name of tolerance” (p. 136). To put it differently, multiculturalism, by consolidating separate cultural spheres, amounts to the preservation of the marginality of minority cultures by a dominating majority culture (p. 135).

How to escape this dilemma? As already anticipated, Gressgård’s ‘solution’, following Lash (1999), Derrida and Lyotard, is an unconditional openness towards the 'other', the unknown, the event, the 'arrivant', or the 'forgotten' which accompanies any identity-formation process (p. 85-86). 'Living with lack', with an awareness of the limitations and inadequacy of our cognitive and evaluative capacities, is then the condition for a community based on difference rather than identity. In this sense, as long as dominant cultural forms are aware of their finitude and historicity and recognize different ways of thinking and acting (p. 137), it is possible "to be together without ‘common being””, “to be bonded without bonds” (p. 85).

Having followed Gressgård all along her challenging philosophical journey, I should confess that I was a bit disappointed to end up onto this very familiar terrain. Her 'solution' to the multicultural dilemma is indeed something heard often times in the literature on multiculturalism (e.g., Kymlicka 2011). Why to embark in such a long 
journey to then arrive at the same, very familiar place where others, who have embarked in similar journeys, have already landed? I know that usually the merry is in the journey itself; but it is also nice to think sometimes that our journey could lead us to undiscovered terrains... True, Gressgård refuses any problem-solving approach (p. 12); she is not after 'solutions' (“I do not intend to develop a new model for dialogue”, p. 12). Yet, she clearly puts forward a model of thought (being open to difference), which, at least to me, seems pretty close to a 'solution'. If so, how feasible is this ‘solution'? How to move from the theoretical, normative level to the practical, empirical or political level? Interestingly, Gressgård also asks these same questions (p. 86, 105), but leave them unanswered, as her quest is indeed exclusively theoretical. But even if we remain within a theoretical perspective, how does her philosophical model of thought cater for those (often the majority in our societies) who refuse to be open to dialogue? How can communities based on difference be more inclusive when they actually exclude those who do not have the intellectual/emotive resources to be open to the arrivant? Are these 'others' less morally valuable that the traditional 'other' (i.e., the diverse in terms of gender, ethnicity, religion, sex, etc.)?

Gressgård’s book is certainly a stimulating philosophical journey into the often taken-for-granted notions of the multicultural debate; but it is also a journey which stops where the dirt road of real life starts. However 'illuminating' her journey might be, it is therefore a partial one, in need of being 'grounded'. 


\section{References}

Alba R and Nee V (1997) Rethinking assimilation theory for a new era of immigration. International Migration Review 31(4): 826-874.

Brader T, Valentino N A, Suhay E (2008) What triggers public opposition to immigration? Anxiety, group cues, and immigration threat. American Journal of Political Science 52(4): 959-978.

Brubaker R (2001) The return of assimilation? Changing perspectives on immigration and its sequels in France, Germany, and the United States. Ethnic and Racial Studies 24(4): 531-548.

Citrin J and Sides J (2008) Immigration and the imagined community in Europe and the United States. Political Studies 56(1): 33-56.

Falzon C (1998) Foucault and social dialogue. London: Routledge.

Kymlicka W (2011) Multicultural citizenship within multination states. Ethnicities 11(3): 281-302.

Lash S (1999) Another modernity. Oxford: Blackwell.

Nagel C R (2009) Rethinking geographies of assimilation. The Professional Geographer 61(3): 400-407. 